Mensaje del Editor

https//dx.doi.org/10.35366/94932

doi: $10.35366 / 94932$

\section{Trilogía COVID-19}

\author{
COVID-19 Trilogy
}

Acad. Dr. Raúl Carrillo-Esper*

L as epidemias han acompañado al ser humano desde que apareció en la tierra. Con el paso del tiempo han impactado en el ejercicio y avances de la medicina, así como en diferentes esferas del quehacer humano como organización social, económica y política, sin dejar a un lado la huella que dejan.

Vivimos tiempos difíciles, una nueva plaga asola a la humanidad. Somos testigos de cómo, a pesar de los grandes avances en la ciencia y tecnología, los cuatro jinetes del apocalipsis, hambre, guerra, peste y muerte, se apoderan de nuestro planeta y lo devastan poco a poco, sin prisa pero sin pausa.

El COVID-19 nos ha venido a enseñar muchas cosas, entre ellas la fuerza de la naturaleza, su superioridad sobre el ser humano y nuestra vulnerabilidad. A pesar de dominar lo inimaginable hace algunos años, el ser humano es derrotado por una partícula viral, forzándolo a reorganizar la vida a como creíamos que era lo ideal.

La práctica de la medicina se ha visto impactada por esta pandemia y hemos visto con asombro cómo aún las grandes potencias mundiales y sus servicios de salud han sido rebasados, y que a pesar de todos los esfuerzos realizados la pandemia sigue incontrolable y el número de contagiados, enfermos y muertos se incrementa día con día.

Hemos cambiado nuestra actitud y aprendimos que el trabajo transdisciplinario para enfrentar la crisis es fundamental. Somos testigos de la reconversión hospitalaria, del desarrollo e implementación de protocolos y del cambio de organización. En este concierto de trabajo en equipo, el anestesiólogo es parte activa en el manejo de la vía aérea y perioperatorio de los pacientes aquejados por COVID-19 y no sólo eso, muchos colegas están en el frente de batalla en la continuidad de atención, poniendo con esto en riesgo su salud e incluso su vida, lo que habla de su patriotismo y del fuerte compromiso con la salud y el pueblo de nuestro país. Mi reconocimiento y respeto a todos los que día a día siguen en el frente de batalla.

El conocimiento científico relacionado al virus SARS-CoV-2 y a la enfermedad COVID-19 es enorme, el número de publicaciones en cada uno de los escenarios de la medicina se incrementa día con día y estar al corriente con toda la información es prácticamente imposible, por lo que aparecen en la literatura, acorde a la especialidad, diversos documentos que sintetizan y recomiendan, con base en la evidencia, las guías de práctica, que se actualizan acorde a lo cambiante de la ciencia médica. Mucho es lo que hemos aprendido, pero aún falta un buen trecho para dominar a la enfermedad.

El Colegio Mexicano de Anestesiología, fiel a su compromiso con la educación médica continua y difusión del conocimiento, dedicó tres números de la Revista Mexicana de Anestesiología, que comprenden los tres últimos del año en curso, a temas exclusivamente dedicados al COVID-19 y la Anestesiología. En esta trilogía se pone al alcance de todos los interesados temas de actualidad relacionados con diferentes facetas de la enfermedad, escritos no sólo por anestesiólogos, sino también por otros especialistas que están involucrados en el abordaje y manejo de pacientes con esta grave enfermedad. La trilogía está integrada por 51 trabajos, escritos por 96 autores, de los cuales 84 son
Anestesiología

Octubre-Diciembre 2020

Vol. 43. No. 4. pp 223-224

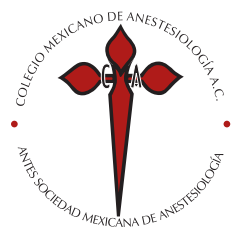

* Editor.

Solicitud de sobretiros:

Acad. Dr. Raúl Carrillo-Esper

Colegio Mexicano de

Anestesiología, A.C.

Revista Mexicana de Anestesiología.

E-mail: cmx@revistacomexane.com

Recibido para publicación: 15-07-2020

Aceptado para publicación:

22-07-2020 
mexicanos y 12 extranjeros, lo que refleja la colaboración multiinstitucional y compromiso de todos los participantes, mi agradecimiento a todos.

Con este número cerramos la trilogía dedicada al COVID-19 para continuar con el trabajo editorial propio de la revista, en el entendido de que, acorde a los avances y nuevos conocimientos, se continuará con la inclusión de trabajos relacionados con la anestesiología, medicina perioperatoria y esta grave enfermedad. Hago una cordial y atenta invitación a que todos los interesados envíen sus trabajos al respecto.

No nos dejemos derrotar por el desaliento y la desesperanza, unidos lograremos derrotar a este enemigo invisible y salir triunfantes. 